\title{
Problem Based Learning Strategy: the Impact on Mathematical Learning Outcomes viewed from Anxiety Levels
}

\author{
Meriyati $^{1}$, Rizkia Shaulita ${ }^{2}$, Lita Nurma Turnip ${ }^{3}$ \\ ${ }^{1}$ Universitas Islam Negeri Raden Intan lampung \\ ${ }^{2,3}$ Universitas Persada Indonesia YAI Jakarta \\ Correspondence Address; meriyati@radenintan.ac.id
}

\begin{abstract}
This study aims to look at the effect of Problem Based Learning (PBL) Strategy and mathematical anxiety towards mathematics learning outcomes. The method used is the quasi-experiment method with a $2 \times 2$ factorial pattern. The data analysis technique is was the two-way analysis of variance (ANAVA) technique. This study discovers that (1) there are differences in mathematics learning outcomes between students who got the Problem Based Learning (PBL) strategy treatment and conventional learning strategies treatment, (2) there are effects of interaction between learning strategies and anxiety on mathematics learning outcomes, (3) there are differences in mathematics learning outcomes of students who have high anxiety level based on the treatments they received, (4) there are differences in mathematics learning outcomes of students who have low anxiety level based on the treatments they received.
\end{abstract}

Keywords: Problem Based Learning (PBL), Anxiety, Mathematics.

\section{INTRODUCTION}

Learning mathematics plays a very important role as a science that utilizes language and as a science that has an accurate nature of solving social problems and supporting knowledge in other fields. Many efforts have been made so that learning outcomes, especially on mathematics subjects, can be increased. The assessment of mathematics learning outcomes is done to find out whether the learning objective been achieved or not. One of the efforts made is applying the right learning strategies. The assumption is based on the selection of appropriate learning strategies for a particular material that strongly supports the learning process and results.

Strategies relate to approaches in delivering material. The strategy must be adjusted to the learning objectives that have been determined (Abell, Appleton, \& Hanuscin, 2010). One strategy that can be used in mathematics learning is the Problem Based Learning which is characterized by the use of real-life problems as a focus for students to learn. With the Problem Based Learning, students are expected to get more skills compared to just memorizing. Starting from problem-solving skills, critical-thinking skills, work skills in groups, interpersonal and communication skills, as well as information searching and processing skills. In addition, learning strategies that affect learning outcomes are other factors that cause low mathematics learning outcomes, including factors that exist within students such as their attitudes toward mathematics.

The development of negative thinking in students as a trigger for the emergence of negative impulses on their attitudes toward mathematics subjects. It can cause anxiety that will have an impact on the low learning outcomes in mathematics. The impact of anxiety on mathematics learning causes students to be unsure of the completion of their mathematics 
learning, their lack of desire to solve mathematical learning problems, and their avoidance in taking mathematics lessons.

Based on previous research, the Problem Based Learning (PBL) strategy had been widely applied in learning (Aisida, 2017; Alfi, Sumarmi, \& Amirudin, 2016; Amir, 2010; Anggraini \& Masykur, 2018; Arifin Handoyo \& Arifin, 2016; Choridah, 2013; Farhan \& Retnawati, 2014; Fitri, 2011; Kartikasari, Rusdi, \& Asyhar, 2016; Maulidiyahwarti, Sumarmi, \& Amirudin, 2016; Murniyati \& Winarto, 2018; Mustofa, Susilo, \& Muhdhar, 2016; Pranawestu, Kharis, \& Mariani, 2012; Primartadi, 2012; Saleh, 2013; Syaifulloh, 2016; Tristanti, 2017; Yustianingsih, Syarifuddin, \& Yerizon, 2017) The research in improving the mathematics learning outcomes are currently being studied (Arifin Handoyo \& Arifin, 2016; Asmawati \& Wuryanto, 2014; Asmoro, 2017; Hasanah, 2016; Kristin \& Rahayu, 2016; Larasati, 2014; Lusianti, 2013; Maulidiyahwarti et al., 2016; Pratiwi \& Santosa, 2013; Primartadi, 2012; Sari, Ridlo, \& Utami, 2016; Sarnoko, Ruminiati, \&Setyosari, 2016; Sukardi, Susilo, \& Zubaidah, 2015; Sumarni \& Susanti, 2016; Tafakur \& Suyanto, 2015; Taufik Aditia \& Muspiroh, 2013; Tyas, 2014; Utami, Hastuti, Yatimah, Padmini, \& Arroyan, 2013; Vahlia \& Sudarman, 2015; Yulianti, An'nur, \& Wati, 2014). However, no research has looked at the effect of Problem Based Learning (PBL) strategy and mathematical anxiety on mathematics learning outcomes. So, the purpose of this study is to look at the effect of Problem Based Learning (PBL) strategy and mathematical anxiety on mathematics learning outcomes.

\section{THE RESEARCH METHODS}

The method used in this research is the quasi-experiment method with a $2 \times 2$ factorial design. The study was conducted in the seventh grade of Junior High School (SMP) 29 Lampung. The target population of the study was all students of SMP 29 Lampung while the population was students of the seventh-grade class 1 and 2. The sample was 30 students for each class who was randomly chosen to be the member of the experimental class and control class using multi-stage cluster random sampling. The research plan is displayed in the following table:

Table 1. The Design of Treatment by Levels $2 \times 2$

\begin{tabular}{ccc}
\hline \multirow{2}{*}{ Anxiety (B) } & \multicolumn{2}{c}{ Learning Strategies } \\
\cline { 2 - 3 } & Problem Based Learning (PBL) (A1) & Conventional (A2) \\
\hline High (B1) & A1B1 & A2B1 \\
Low (B2) & A1B2 & A2B2 \\
\hline
\end{tabular}

To determine the anxiety level of the two classes, a high and low anxiety questionnaire was given. The results of the questionnaire are sorted from high to low. The next stage, the $27 \%$ of the highest-ranked students were classified as a group of students who had high anxiety level and $27 \%$ of the lowest-ranked students was classified as a group of students who had low anxiety level. The consideration of taking $27 \%$ of the students for each high and low anxiety 
groups was based on the determination of the high group and the low group which could be determined between $25 \%$ and $33 \%$.

\section{Data Analysis Techniques.}

This study employed a two-way analysis of variance (ANAVA) technique. By using this technique, it was intended to determine the significance of the interactions occurred between learning strategies and anxiety towards the mathematics learning outcomes. Two-way ANAVA was used because this research has more than one independent variable. Before hypothetical testing was carried out, the pre-requisite tests were carried out first, namely the normality test and the data homogeneity test.

\section{Prerequisite Tests}

The normality and data homogeneity test needed to be done. The data normality test was done through the Lilliefors test while the homogeneity test was carried out by the Bartlett test. The tests were conducted to ensure that the data used was actually from the normally distributed data and originates from a homogeneous population.

\section{Hypothetical Test}

This test was intended to see which interaction effects or simple effects were higher. As for the statistical hypothesis of this research are :

\section{a. Hypothesis 1:}

$$
\begin{aligned}
& \mathrm{H}_{0}: \mu_{\mathrm{A} 1} \leq \mu_{\mathrm{A} 2} \\
& \mathrm{H}_{1}: \mu_{\mathrm{A} 1}>\mu_{\mathrm{A} 2}
\end{aligned}
$$

\section{c. Hypothesis 3:}

$$
\begin{aligned}
& \mathrm{H}_{0}: \mu_{\mathrm{A} 1 \mathrm{~B} 1} \leq \mu_{\mathrm{A} 2 \mathrm{~B} 1} \\
& \mathrm{H}_{1}: \mu_{\mathrm{A} 1 \mathrm{~B} 1}>\mu_{\mathrm{A} 2 \mathrm{~B} 1}
\end{aligned}
$$

b. Hypothesis 2:

$$
\begin{aligned}
& \mathrm{H}_{0}: \mu_{\mathrm{A} 2 \mathrm{~B} 2} \leq \mu_{\mathrm{A} 2 \mathrm{~B} 2} \\
& \mathrm{H}_{1}: \mu_{\mathrm{A} 2 \mathrm{~B} 2}<\mu_{\mathrm{A} 2 \mathrm{~B} 2}
\end{aligned}
$$

\section{d. Hypothesis 4 :}

$\mathrm{H}_{0}:$ Interaksi $A \times B=0$

$\mathrm{H}_{1}$ : Interaksi $A \times B \neq 0$

THE RESULTS OF THE RESEARCH AND THE DISCUSSION

Table 1. The Description of the Research Data

\begin{tabular}{cccc}
\hline \multirow{2}{*}{ Anxiety(B) } & \multicolumn{3}{c}{ Learning Strategy (A) } \\
\cline { 2 - 4 } & Problem based Learning $(\boldsymbol{P B L})(\mathbf{A 1})$ & Conventional (A2) & Total \\
\hline \multirow{2}{*}{ High (B1) } & $\mathrm{n}=30$ & $\mathrm{n}=30$ & $\mathrm{n}=60$ \\
& $\mathrm{SD}=2,43$ & $\mathrm{SD}=2,63$ & $\mathrm{SD}=4,74$ \\
& $\bar{X}=20,00$ & $\bar{X}=12,52$ & $\overline{\boldsymbol{X}}=16,26$ \\
Low (B2) & $\mathrm{n}=30$ & $\mathrm{n}=30$ & $\mathrm{n}=60$ \\
& $\mathrm{SD}=3,50$ & $\mathrm{SD}=3,14$ & $\mathrm{SD}=3,49$ \\
& $\bar{X}=12,29$ & $\bar{X}=15,07$ & $\overline{\boldsymbol{X}}=13,68$ \\
Total & $\mathrm{N}=60$ & $\mathrm{~N}=60$ & $\mathrm{~N}=120$ \\
& $\mathrm{SD}=4,58$ & $\mathrm{SD}=3,69$ & $\mathrm{SD}=4,13$ \\
& $\overline{\boldsymbol{X}}=16,14$ & $\overline{\boldsymbol{X}}=13,79$ & $\overline{\boldsymbol{X}}=13,96$ \\
\hline
\end{tabular}




\section{Description: \\ n}

Primary : : Standard Deviation

$\bar{X} \quad$ : Average Score (Mean)

The two-way variance analysis with interaction ( $2 \times 2$ ANAVA) was conducted. With the intention to see the different effects of the treatments, namely the influence of learning strategies and anxiety and their interactions with mathematics learning outcomes as presented in Table 2.

Table 2. Two-way ANAVA toward the Mathematics Learning Outcomes

\begin{tabular}{ccccccc}
\hline \multirow{2}{*}{ Source of Variance } & \multirow{2}{*}{$\mathrm{Db}$} & $\mathrm{Jk}$ & $\mathrm{RK}=\mathrm{JK} / \mathrm{db}$ & $\mathrm{F}_{\mathrm{c}}=\mathrm{RK} / \mathrm{RKD}$ & \multicolumn{2}{c}{$\mathrm{F}_{\text {table }}$} \\
\hline Learning Strategy (A) & 1 & 164,779 & 164,775 & $17,10^{*}$ & 0,05 & 0,01 \\
\hline Anxiety (B) & 1 & 201,207 & 200,207 & $22,208^{*}$ & 3,92 & 6,84 \\
Interaction Factor (AxB) & 1 & 754,406 & 754,406 & $82,11^{*}$ & & \\
In (D) & 116 & 109,640 & 9,565 & - & - & - \\
Total (T) & 119 & 2260,954 & - & - & - & - \\
\hline
\end{tabular}

\section{Description:}

$\mathrm{Db} \quad$ : Degree of freedom of the variance

$\mathrm{Jk} \quad$ : The squared total of the source of variance number

RK : The average number of squared sources of variance

RKD : The average number of the squared number in groups

*) Significance

Fc : The value of $F_{\text {critical }}$

$\mathrm{F}_{\mathrm{t}} \quad$ : The value of $\mathrm{F}_{\text {table }}$

\section{First Hypothetical Test}

Students' mathematics learning outcomes who learned with Problem Based Learning strategy were higher than the mathematics learning outcomes of the students who learned using conventional strategy. The results of calculations using two-way ANAVA show that $F_{c}=17.31$ which is greater than $F_{t}=3.92$ at the 0.05 significance level. $\left.>F(0.05)(1,116)=6.84\right)$ Likewise, the value of $F_{c}$ is greater than $F_{t}=6.84$ at the significant level of $0.01(F c=17.31>F(0.01)($ $1.116)=6.4$. It can be concluded that $\mathrm{H}_{0}$ was rejected and $\mathrm{H}_{1}$ was accepted. Thus, the learning outcomes of students that learned using Problem Based Learning strategy was different from the group that learned using conventional strategy.

The analysis was followed by Tukey HSD test with $=60 \mathrm{k}=2 \mathrm{dk}=58 \mathrm{KRD}=9.565$ and the calculation of $\mathrm{q}$ at the 0.05 and 0.01 significance levels obtained by HSD $=1.118$ and HSD $=1.477$ mean difference $\mu A_{1}=16.15$ and $\mu A_{2}=13.80$ is $2.35>\mathrm{HSD}=1.118$ at $p<0.05$ and 2.35> $\mathrm{HSD}=1.477$ at $\mathrm{p}<0.01$. Thus, it was concluded that $\mathrm{H}_{0}$ was rejected and $\mathrm{H}_{1}$ was accepted. The mathematics learning outcomes of the students who got the PBL treatment were higher than the mathematics learning outcomes of the students who got conventional strategy treatment. 


\section{The Second Hypothetical Test}

There was an interaction effect between environmental and neighborhood conditions with the learning strategy on mathematics learning outcomes. Based on the ANAVA test, it was obtained that the value of $F_{c}=82.11>F_{c}=3.92(\alpha=0.05)$ and $F_{c}=82.11>6.84(\alpha=0.01)$, this means that $\mathrm{H}_{0}$ was rejected and $\mathrm{H}_{1}$ was accepted (interaction $\left.\mathrm{AXB}>0\right)$ or $\left(\mathrm{uA}_{1} \mathrm{~B}_{1}=20.00>\mathrm{uA}_{2}\right.$ $\left.\mathrm{B}_{1}=12.53\right)$ and $\left.\mathrm{uA}_{1} \mathrm{~B}_{2}=12.30<\mu \mathrm{A}_{2} \mathrm{~B}_{2}=15.06\right)$. It can be concluded that there was an interaction effect between the application of learning strategies and anxiety on mathematics learning outcomes.

\section{The Third Hypothetical Test}

The mathematics learning outcomes of the students who have high anxiety level and were given the PBL treatment was higher than the mathematics learning outcomes of the students who were given the conventional strategy treatment. The results of calculations using two-way ANAVA obtained $\mathrm{Fc}=82.11$ then $\mathrm{F}_{\mathrm{t}}=3.92$ with a significance level of 0.05 and 6.84 for the significance level of 0.01. The data indicating that $\left(\mathrm{Fc}=82.11\right.$ and $\mathrm{F}_{\mathrm{t}}=3.92(0.01: 1116)=6.84$. This means that $\mathrm{H}_{0}$ was rejected and $\mathrm{H}_{1}$ was accepted. Thus, the learning outcome of the students who have a high anxiety level treated with the PBL strategy was different from the learning outcome of students who were treated with the conventional learning strategy.

Furthermore, the Tukey HSD test with $\mathrm{n}=30$ and $\mathrm{k}=2 \mathrm{dk}=58 \mathrm{KRD}=9.565$ and calculations at the significance level of 0.05 and 0.01 obtained by HSD $=1.597$ and 2.123. The mean that the difference of $\mu \mathrm{A}_{1} \mathrm{~B}_{1}=20.00>\mu \mathrm{A}_{2} \mathrm{~B}_{1}=12.53$ is $7.47>\mathrm{HSD}=1.597(\mathrm{p}<0.05)$ and 7.47> $\mathrm{HSD}=2.123(\mathrm{p}<0.01)$. it can be concluded that $\mathrm{H}_{0}$ was rejected and $\mathrm{H}_{1}$ was accepted. Thus, the learning outcome of the students who have a high anxiety level treated with the PBL strategy was higher than the learning outcome of students who were treated with the conventional learning strategy.

\section{The Fourth Hypothetical Test}

The learning outcome of the students who have low anxiety level and were treated with PBL strategy was lower than the students who were treated with the conventional learning strategy. $\mathrm{Fc}=82.11$ then $\mathrm{F}_{\mathrm{t}}=3.92$ for the significance level of 0.05 and 6.84 for the significance level of 0.01 , it turns out that $\mathrm{Fc}=82.11>\mathrm{F}_{\mathrm{t}(0.05)} ; 1.116=3.92$ and $\mathrm{Fc}=82.11>\mathrm{F}_{\mathrm{t}}(0.011 .116)$ = 6.84). This means that $\mathrm{H}_{0}$ was rejected and $\mathrm{H}_{1}$ was accepted. It is concluded that the mathematics learning outcome of the students who have low anxiety and were treated with PBL strategy was different from students' mathematics learning outcomes who were treated with conventional strategy.

Furthermore, the Tukey HSD test with $\mathrm{n}=30 \mathrm{k}=2 \mathrm{KRD}=9.565$ and calculations at the significance level of 0.05 and 0.01 obtained by $\mathrm{HSD}=1.597$ and 2.123. Mean difference $\mathrm{uA}_{1}$ $\mathrm{B}_{2}=12.30>\mathrm{uA}_{2} \mathrm{~B}_{2}=15.06$ was 2.76> $1.597(\mathrm{p}<0.05)$ and 2.76,> 2,123 (p <0.01). It means that $\mathrm{H}_{0}$ was rejected and $\mathrm{H}_{1}$ was accepted. It can be concluded that the learning outcome of the students with low anxiety level and were treated with PBL strategy is lower than the students who were treated with conventional strategy.

Mathematics is a science that is often found in everyday life. The needs of human life become one of the histories of mathematics. The conveniences obtained from mathematics make life well-fulfilled. One of the important goals of mathematics is to be able to help people 
solve problems in daily life easier. However, many people do not realize the importance of learning mathematics in their daily lives. Generally, mathematical knowledge is obtained from a process involving the abstract cognitive nature, has a primary goal in numbers, and is able to solve problems in everyday life. The understanding of mathematics for elementary school children is learning numbers and forms and measurements in mathematical concepts, understanding the numeracy, reading numbers, operating mathematical numbers, teaching basic concepts, and being the foundation for further education. One of the successes of learning mathematics can be seen from the mathematics learning outcomes.

The primary learning outcomes of mathematics are the ability or mastery possessed by students after learning which can be seen from cognitive, affective, and psychomotor aspects. Assessment of learning outcomes is influenced by factors that are closely related to the educational process such as row, input, interest, and readiness in learning. However, there are components that influence the mathematics learning outcomes, among others: teachers, materials given in educational conventions, forms of communication, household situations and conditions, social environment, economic conditions, and the state of learning the culture.

Learning mathematics itself requires full concentration. This makes students unable to think casually because concentration is heavy mental work. Relaxing conditions are the best conditions for learning mathematics if the learning strategies used are appropriate and relevant to their interests and learning abilities. For those who have high anxiety, their learning outcomes will be lower if the learning strategies used do not match their characteristics since each strategy has certain characteristics with all its strengths and weaknesses.

Some opinions explain that some of the advantages in the application of Problem Based Learning include: (a) Providing opportunities for students to solve problems according to their individual ways or learning styles. By knowing the learning styles of each individual, we are expected to help to adjust to the approach we use in learning. (b) Development of critical thinking skills. (c) Learners are trained to develop ways to discover, question, articulate, explain or describe, consider or make judgments, and make a decision (decision-making). Thus, students apply a work process through a problematic situation that contains problems. Furthermore, the weaknesses in the application of Problem Based Learning include: (a) The Problem Based Learning requires a long time to apply. (b) Need to be supported by books that can be used in learning activities, especially in making questions.

Students who experience anxiety in mathematical learning are called mathematical anxiety. Many factors cause a person's anxiety in mathematical learning including the inability to understand mathematics learning and the development of antipathy in mathematics learning. This impact can cause anxiety in students which can affect the learning outcomes. Students' anxiety can be recognized through three components, namely (1), psychological components in the form of anxiety, nervousness, tension, insecurity, fear, and surprise, (2) physiological components such as palpitations, cold sweat in the palms, the increase of blood pressure, and (3) social in the form of behavior shows by individuals in the form of behavior and sleep disturbance. 
Someone in an anxious condition will not concentrate, consequently, it can reduce their concentration power. Mathematical anxiety is a type of disease that refers to the atmosphere of an unhealthy heart. The worst impact of anxiety can cause a person to be depressed, panic and helpless, nervous, and afraid.

\section{CONCLUSION AND SUGGESTION}

Based on the hypothetical test and discussion, it can be concluded that (1) Overall, there are significant differences in student learning outcomes treated with Problem Based Learning (PBL) strategy with students treated with conventional learning strategy, (2) there is an interaction effect of learning strategies with anxiety on mathematics learning outcomes, (3) the mathematics learning outcomes of the students who have high anxiety and were given the Problem Based Learning (PBL) strategy treatment are higher than the learning outcomes of students who are treated with conventional learning strategy, (4) the mathematics learning outcomes of students who have low anxiety and were given the Problem Based Learning (PBL) strategy treatment have no difference compared to the students who are treated with conventional learning strategy. Suggestions that can be given for further research is to be able to examine problems with a wider range and try to use other learning strategies to maximize various aspects of mathematics learning.

\section{REFERENCES}

Abell, S. K., Appleton, K., \& Hanuscin, D. L. (2010). Designing and Teaching the Elementary Science Methods Course. New York: Firt Published.

Aisida, S. (2017). Aplikasi Model Problem Based Learning sebagai Motivasi dalam Pembelajaran Fiqih. An-Nuha, 4(1), 18-39.

Alfi, C., Sumarmi, \& Amirudin, A. (2016). Pengaruh Pembelajaran Geografi Berbasis Masalah dengan Blended Learning Terhadap Kemampuan Berpikir Kritis Siswa SMA. Jurnal Pendidikan: Teori, Penelitian, Dan Pengembangan, 1(4), 597-602.

Amir, M. T. (2010). Inovasi Pendidikan Melalui Problem Based Learning. Jakarta: Kencana Prenada Media Group.

Anggraini, N., \& Masykur, R. (2018). Modul Matematika Berdasarkan Model Pembelajaran Problem Based Learning Materi Pokok Trigonometri. Desimal : Jurnal Matematika, 1(2), 217-228.

Arifin Handoyo, N., \& Arifin, Z. (2016). Pengaruh Inquiry Learning Dan Problem Based Learning Terhadap Hasil Belajar PKKR Ditinjau dari Motivasi Belajar. Jurnal Pendidikan Vokasi, 6(1), 31-42.

Asmawati, R., \& Wuryanto. (2014). Keefektifan Model Pembelajaran LC 5E Dan TSTS Berbantuan LKPD Terhadap Hasil Belajar. Jurnal Kreano, 5(1), 26-32.

Asmoro, A. W. (2017). Peningkatan Aktivitas Dan Hasil Belajar Menggunakan Model Pembelajaran STAD Pada Materi Barisan Dan Deret Bilangan. Jurnal Edumath, 3(1), 
$28-33$.

Choridah, D. T. (2013). Peran pembelajaran berbasis masalah untuk meningkatkan kemampuan komunikasi dan berpikir kreatif serta disposisi matematis siswa SMA. Jurnal Ilmiah Program Studi Matrmatika STKIP Siliwangi Bandung, 2(2), 194-202.

Farhan, M., \& Retnawati, H. (2014). Keefektifan PBL Dan IBL Ditinjau dari Prestasi Belajar, Kemampuan Representasi Matematis, dan Motivasi Belajar. Jurnal Riset Pendidikan Matematika, 1(2), 227-239.

Fitri, A. (2011). Pengembangan Perangkat Pembelajaran Statistika Dasar Bermuatan Pendidikan Karakter Dengan Metode Problem Based Learning. Jurnal PP, 1(2), 159165 .

Hasanah, U. (2016). Penerapan Strategi Pembelajaran Mind Mapping Untuk Meningkatkan Hasil Belajar Peserta Didik Pada Mata Pelajaran Fiqih Kelas VII A MTS Nurul Islam Air Bakoman Kabupaten Tanggamus. Al-Idarah : Jurnal Kependidikan Islam, 6(2), 41-60.

Kartikasari, I., Rusdi, M., \& Asyhar, R. (2016). Konstruksi dan Validasi Model Desain Pembelajaran Berbasis Masalah untuk Mengembangkan Kreativitas Siswa. Jurnal EduSains, 5(1), 56-68.

Kristin, F., \& Rahayu, D. (2016). Pengaruh Penerapan Model Pembelajaran Discovery Learning Terhadap Hasil Belajar IPS Pada Siswa Kelas 4 SD. Scholaria, 6(1), 84-92.

Larasati, F. F. (2014). Efektivitas Student Achievment Division Berbantu Monopoli Terhadap Aktivitas dan Hasil Belajar. Economic Education Analysis Journal, 3(1), 1-10.

Lusianti, M. (2013). Penerapan Metode Diskusi Syndicate Group Untuk Meningkatkan Aktivitas dan Hasil Belajar Pada Pokok Bahasan Mendeskripsikan Hubungan Antara Kelangkaan Sumber Daya Dengan Kebutuhan Manusia yang Tidak Terbatas. Economic Education Analysis Journal, 2(3), 82-87.

Maulidiyahwarti, G., Sumarmi, \& Amirudin, A. (2016). Pengaruh Model Problem Based Learning Berbasis Outdoor Study Terhadap Hasil Belajar Siswa Kelas XI IIS SMA. Jurnal Pendidikan: Teori, Penelitian, Dan Pengembangan, 1(2), 94-100.

Murniyati, \& Winarto. (2018). Perbedaan Penerapan Model PjBL dan PBL ditinjau dari Pencapaian Keterampilan Proses Siswa. PSEJ ( Pancasakti Science Education Journal ), 3(1), 25-33.

Mustofa, Z., Susilo, H., \& Muhdhar, M. H. I. Al. (2016). Penerapan Model Pembelajaran Problem Based Learning Melalui Pendekatan Kontekstual Berbasis Lesson Study Untuk Meningkatkan Kemampuan Memecahkan Masalah Dan Hasil Belajar Kognitif Siswa SMA. Jurnal Pendidikan: Teori, Penelitian, Dan Pengembangan, 1(5), 885-889.

Pranawestu, A., Kharis, M., \& Mariani, S. (2012). Keefektifan Problem Based Learning Berbantuan CABRI 3D Berbasis Karakter Terhadap Kemampuan Spasial. Unnes Journal of Mathematics Education, 1(2), 1-6.

Pratiwi, K. K., \& Santosa, N. B. (2013). Pengaruh Pembelajaran Team Assisted 
Individualization (TAI) Berbantuan Media Smart And Interesting Card (SIC) Terhadap Hasil Belajar Siswa. Jurnal Inovasi Pendidikan Kimia, 7(2), 1210-1219.

Primartadi, A. (2012). Pengaruh Metode Student Teams-Achievement Division (STAD) dan Problem Based Learning Terhadap Hasil Belajar Ditinjau Dari Potensi Akademik Siswa SMK Otomotif. Jurnal Pendidikan Vokasi, 2(2), 143-153.

Saleh, M. (2013). Strategi Pembelajaran Fiqh Dengan Problem Based Learning. Jurnal Ilmiah DIDAKTIKA, XIV(1), 190-220.

Sari, E. N., Ridlo, S., \& Utami, N. R. (2016). Pengaruh Model Pembelajaran Discovery Learning Dengan Mind Mapping Terhadap Hasil Belajar Siswa Pada Materi SEL di SMA. Unnes Science Education Journal, 5(3), 1403-1407.

Sarnoko, Ruminiati, \& Setyosari, P. (2016). Penerapan Pendekatan SAVI Berbantuan Video Pembelajaran Untuk Meningkatkan Aktivitas dan Hasil Belajar IPS Siswa Kelas IV SDN 1 Sanan Girimarto Wonogiri. Jurnal Pendidikan: Teori, Penelitian Dan Pengembangan, 1(7), 1235-1241.

Sukardi, A. D., Susilo, H., \& Zubaidah, S. (2015). Pengaruh Pembelajaran Reciprocal Teaching Berbantuan Peta Pikiran ( Mind Map) terhadap Kemampuan Metakognitif dan Hasil Belajar Siswa SMA. Jurnal Pendidikan Sains, 3(2), 81-89.

Sumarni, \& Susanti, N. (2016). Penerapan Metode Pembelajaran Kooperatif Tipe Student Teams Achievement Divisions (STAD ) Untuk Meningkatkan Hasil Belajar Mahasiswa Pada Mata Kuliah Perencanaan Pembelajaran Ekonomi. Economica, 4(1), 109-123.

Syaifulloh, A. (2016). Pengaruh Strategi Problem-Based Learning (PBL) terhadap Motivasi dan Hasil Belajar Peserta Didik pada Mata Pelajaran Fiqih di MA Khozinatul 'Ulum Blora Jawa Tengah. Wahana Akademika, 3(2), 121-136.

Tafakur, \& Suyanto, W. (2015). Pengaruh Cooperative Project-Based Learning terhadap Motivasi dan Hasil Belajar Praktik "Perbaikan Motor Otomotif" di SMKN 1 Seyegan. Jurnal Pendidikan Vokasi, 5(1), 117-131.

Taufik Aditia, M., \& Muspiroh, N. (2013). Pengembangan Modul Pembelajaran Berbasis Sains, Lingkungan, Teknologi, Masyarakat dan Islam ( Salingtemasis) Dalam Meningkatkan Hasil Belajar Siswa Pada Konsep Ekosistem Kelas X di SMA NU Lemahabang Kabupaten Cirebon. Jurnal Science Educatia, 2(2), 1-20.

Tristanti, L. B. (2017). Pengaruh Model Pembelajaran Kooperatif Tipe TAI Dan Problem Based Learning (PBL) Terhadap Pemahaman Konsep Bangun Ruang Siswa. Jurnal Pendidikan Matematika FKIP Univ. Muhammadiyah Metro, 6(3), 338-349.

Tyas, E. N. (2014). Peningkatan Keterampilan Proses dan Hasil Belajar Subtema Tugasku Sehari-hari di Rumah Menggunakan Model Pembelajaran SAVI Pada Siswa Kelas II SDN 1 Bolo. Scholaria, 4(3), 68-82.

Utami, B., Hastuti, B., Yatimah, S., Padmini, S., \& Arroyan, F. (2013). Penerapan Siklus Belajar 5E Disertai LKS Untuk Peningkatan Kualitas Proses dan Hasil Belajar Kimia. Cakrawala Pendidikan, 32(2), 315-325. 
Vahlia, I., \& Sudarman, S. W. (2015). Penerapan model pembelajaran berbalik ( reciprocal teaching ) ditinjau dari aktivitas dan hasil belajar siswa. Jurnal Pendidikan Matematika FKIP Univ. Muhammadiyah Metro, 4(1), 59-66.

Yulianti, H., An'nur, S., \& Wati, M. (2014). Meningkatkan Hasil Belajar Siswa Pada Materi Ajar Listrik Statis Dengan Pendekatan Problem Posing. Berkala Ilmiah Pendidikan Fisika, 2(3), 244-252.

Yustianingsih, R., Syarifuddin, H., \& Yerizon. (2017). Pengembangan Perangkat Pembelajaran Matematika Berbasis Problem Based Learning (Pbl) Untuk Meningkatkan Kemampuan Pemecahan Masalah Peserta Didik Kelas VII. Jurnal JNPM ( Jurnal Nasional Pendidikan Matematika ), 1(2), 258-274. 